\title{
Reconstructed Dynamics of Rapid Extinctions of Chaparral-Requiring Birds in Urban Habitat Islands
}

\author{
MICHAEL E. SOULÉ* \\ School of Natural Resources \\ University of Michigan \\ Ann Arbor, Michigan, U.S.A. 48109 \\ DOUGLAS T. BOLGER \\ ALLISON C. ALBERTS \\ Department of Biology, C-016 \\ University of California, San Diego \\ La Jolla, California, U.S.A. 92093

\section{JOHN WRIGHT $\dagger$ \\ MARINA SORICE $\dagger$ \\ SCOTT HILL}

\begin{abstract}
The distribution of native, chaparral-requiring bird species was determined for 37 isolated fragments of canyon babitat ranging in size from 0.4 to 104 bectares in coastal, urban San Diego County, California The area of chaparral babitat and canyon age (time since isolation of the babitat fragment) explains most of the variation in the number of chaparral-requiring bird species. In addition, the distribution of native predators may influence species number. There is statistical evidence that coyotes control the populations of smaller predators such as foxes and domestic cats. The absence of coyotes may lead to bigher levels of predation by a process of mesopredator release. The distance of canyons from other patches of chaparral babitat does not add significantly to the explained variance in chaparralrequiring species number-probably because of the virtual inability of most chaparral-requiring species to disperse through developed areas and nonscrub habitats. These results and other lines of evidence suggest that chaparralrequiring birds in isolated canyons bave very bigh rates of extinction, in part because of their low vagility. The best predictors of vulnerability of the individual species are their abundances (densities) in undisturbed habitat and their
\end{abstract}

"Correspondence and requests for reprints sbould be addressed to this author.

†Correspondence to these authors should be sent care of Michael E. Soulé.

Paper submitted 6/10/87; revised manuscript accepted 8/5/87.
Resumen: En el condado urbano de San Diego, California, 37 fragmentos de babitat de cañón que varian de tamaño de 0.4 a 104 bectares, fueron examinados para determinar la distribución de especies de aves nativas que requieren de chaparral. El tamaño del área de babitat de chaparral y la edad del cañón (tiempo transcurrido desde que ocurrió el aislamiento del fragmento de babitat) explican la mayor parte de la variación en el número de especies de aves que requieren de este babitat. Asi mismo, la distribución de depredadores nativos puede influenciar el número de especies. Existen evidencias estadísticas de que los coyotes controlan las poblaciones de depredadores menores tales como los zorros y los gatos domésticos. La ausencia de coyotes puede conducir a niveles de depredación mas altos mediante un proceso de liberación de mesodepredadores. $\mathrm{El}$ ais. lamiento de cañones con respecto a otros pedazos de babitat de chaparral no incrementa significativamente la variancia en el número de especies que requieren chaparralprobablemente debido a la virtual inbabilitad de la mayoría de las especies que requieren chaparral para dispersarse en áreas desarrolladas y en habitats no-arbustivos. Estos re. sultados y otras evidencias sugieren que las aves que re. quieren chaparral en los cañones aislados tienen muy altas tasas de extinción, en parte debido a su baja dispersabilidad. Los mejores pronosticadores de la vulnerabilidad de una especie en particular son su abundancia (densidad) en babitats no perturbados y el tamaño de sus cuerpos; juntas, estas dos variables explican el $95 \%$ de la variación de su residen. 
body sizes; togetber these two variables account for 95 per. cent of the variation in canyon occupancy. A bypothesis is proposed to account for the similarity between the steep slopes of species-area curves for chaparral-requiring birds and the slopes for some forest birds on small islands or in habitat fragments. The provision of corridors appears to be the most effective design and planning feature for preventing the elimination of chaparral-requiring species in a fragmented landscape.

\section{Introduction}

In many places the increasing attrition of habitat is accompanied by fragmentation of the remaining patches. The analysis of fragmentation and its consequences has been facilitated by the study of species-area patterns in groups of oceanic and continental islands (MacArthur \& Wilson 1967) and by the documentation of "relaxation" of species-area curves for archipelagoes of continental islands (land-bridge) and in groups of habitat islands (Soulé \& Sloan 1966, Diamond 1972, Terborgh 1974, Brown 1978, Wilcox 1978, Diamond 1984, Patterson 1984, Lawlor 1986, Heaney 1986, Newmark 1987; also see Biological Journal of the Linnaean Society 1986; 28 [ $1 \& 2]$ ). Faunal collapse in isolated habitat fragments has been extensively documented, especially on continental shelf islands (Diamond 1972, Terborgh 1975 , Case 1975, Soulé et al. 1979) and in recently isolated forest fragments in rural areas (Burgess \& Sharpe 1981, Whitcomb et al. 1981, Lynch \& Whigham 1984, Wilcove et al. 1986). This is the first in a series of reports on the biogeographical consequences of recent habitat fragmentation in a Mediterranean scrub landscape in coastal, southern California.

Relatively few studies have been conducted in Mediterranean scrub habitats, especially in urban contexts. Many Mediterranean scrub habitats are characterized by high species diversity ( $\alpha$-diversity) and by high rates of geographic replacement of species within a habitat type ( $\gamma$-diversity) (Cody 1983). The latter feature, and the likelihood of low vagility of the endemic species in these habitats, may predispose Mediterranean scrub habitats, when fragmented, to higher rates of local extinction than many other temperate zone communities (e.g., see Fig. 10 in Cody 1986, Jones et al. 1985).

The mesas and hills of the coastal region of southern San Diego County are penetrated by valleys extending into the mountainous backcountry. These valleys and their flood plains contain seasonal rivers and streams, and some have well-developed riparian habitat dominated by sycamore (Platanus racemosa) and willows (Salix ssp.). On a smaller scale, the coastal plain is dissected by systems of dendritic, steep-sided canyons. cia en el cañón. Una bipótesis es propuesta para explicar la similaridad entre las fuertes pendientes de las curvas de es. pecies-área para las aves que requieren cbaparral y las pendientes para algunas aves de bosque en pequeñas islas o en babitats fragmentados. La provisión de corredores parece ser el diseño y el rasgo de la planificación más efectivo para prevenir la eliminación de especies que requieren chaparral en un paisaje fragmentado.

Canyons in undeveloped areas rarely have surface water or riparian habitat, but in urban areas runoff and irriga. tion frequently permit the establishment of willows and other mesic species.

The term chaparral is sometimes used generically for the Mediterranean type scrub in this region that extends from sea level to over 2000 meters in places. A major component of this vegetation is "coastal sage-scrub," dominated by California sagebrush (Artemisia californica), wild buckwheat (Eriogonum fasciculatum), and black sage (Salvia mellifera). Depending partly on slope and orientation, the coastal canyons may also have stands of chamise (Adenostoma fasciculatum), scrub oak (Quercus dumosa), and many other genera (Rbus, Coeanothus, Baccharis, etc.). Here, the term chaparral is used in the broadest sense to refer to all the native scrub habitats.

During the settlement and urbanization of this region, the steepness of the canyons has impeded development. As a result, canyons became the natural boundaries for many neighborhoods, and, until recently, these canyons provided an extensive, interconnecting system of natural open space hosting a rich biota of native wildlife. In recent years, however, both the availability of modern earth-moving equipment and the escalating land values in Southern California have led to the filling, terracing, and fragmentation of these canyons. Also, many of the larger canyons and valleys have been used for the construction of major roads and interstate highways. A significant fraction of the riparian and canyon habitats in the city of San Diego has disappeared altogether, and much of the remaining canyon habitat within the city exists only as isolated remnants, many of which are highly disturbed. In this paper we document some of the effects of fragmentation of canyons on the native chaparral birds inhabiting them.

\section{Methods}

The Birds

For biogeographic purposes, the local birds can be placed in three ecological categories: 1) those that re- 
quire chaparral habitat for breeding in this region-the chaparral-requiring species (Table 1); 2) those locally breeding species that are year-round residents but do not have an absolute requirement for chaparral-such as the Common Flicker (Colaptes auratus), the House Finch (Carpodacus mexicanus), and Scrub Jay (Aphelocoma coerulescens); 3 ) migratory species that rarely if ever breed locally-for example, the White-crowned Sparrow (Zonotrichia leucocephallus). We refer to categories two and three as facultative chaparral species. Many facultative chaparral species frequently feed and breed in exotic, ornamental vegetation in nonnative habitats such as yards and parks. In addition, most facultative chaparral species prefer to nest in trees and other nonnative habitats and are capable of relatively long flights. This study is restricted to chaparralrequiring bird species (scientific names listed in Table 1) because our primary objective was to describe the consequences of fragmentation in this habitat. Facultative chaparral birds would respond little if at all to fragmentation, and our preliminary results collected during the course of this study (unpublished data) seem to confirm this.

Chaparral-requiring species rarely fly far. When flying, they usually ascend no higher than a meter or so above the vegetation. Their feeding behavior also reflects this lack of vagility. The California Thrasher, Rufous-sided towhee, California Quail, and Roadrunner feed on or near the ground. Bewick's Wren and the Wrentit feed almost exclusively within the bushes. Black-tailed Gnatcatchers feed on insects on the edges and near the tops of bushes and sometimes hawk for insects immediately above the bushes. Although chaparral-requiring species are found mostly in scrub habitats, two of the eight chaparral-requiring species, the Roadrunner and the California Quail, will feed in open or grassy areas adjacent to chaparral habitat, where they return for cover. Some of the chaparral-requiring species, including the Rufous-sided Towhee and Bewick's Wren, will occasionally be found in dense, ornamental vegetation in yards or parks. The distribution of chaparral-requiring birds in the study sites (canyons) is in Table 2.

Table 1. Common and scientific names of the chaparral-requiring bird species in the canyons.

California Quail (Callipepla califormica)

Greater Roadrunner (Geococcyx californianus)

Wrentit (Chamaea fasciata)

Bewick's Wren (Thryomanes bewickii)

Cactus Wren (Camplyorbyncbus brunneicapillus)

Black-tailed Gnatcatcher (Polioptila melanura)

California Thrasher (Toxostoma redivivum)

Rufous-sided Towhee (Pipilo erytbropbthalmus)

\section{Biogeographic Variables}

Most of the study locales are canyons, though a few are parks or other sites that contain slopes and mesa top, natural habitat. For simplicity, we refer to all sites as "canyons," defined operationally as fragments of unde. veloped land that retain some native chaparral vegetation. Most of our canyons have some slopes greater than 25 percent. As shown in Figure 1, all are surrounded by development. In selecting the 37 study locales (Table 3 ), we attempted to include sites that are representative of the range of both the sizes of canyons in the San Diego area and the amount of elapsed time since the canyons were isolated by development.

The age of a particular canyon (Table 3 ) is the number of years since it was isolated by development from a patch of habitat of equal or larger size. In most cases this is equivalent to the canyon's isolation from the main canyon-mesa system, or a large section of it. Ages were determined from aerial photographs, which clearly show the removal of vegetation, and from the subdivision records of the City of San Diego Building Department. In some cases we depended on the latter method because of the long intervals (ca 20 years) between photographic surveys in the early part of this century. When both procedures could be used, they usually gave ages within two or three years of each other.

Areas of the canyons (Table 3) were determined from contour maps produced from acrial photographs, obtained from the planning departments of the city of San Diego and San Diego County. For this purpose, canyon borders were considered to be either backyard fence lines or the edges of streets where there were no houses. Area measurements were made with an Apple computer digitizing tablet. We also estimated the percentage of each site that still retains natural cover ("\% Chaparral" in Table 3) from the maps and by visual inspection from the ground. To obtain an estimate of the area of natural chaparral habitat in each canyon ("Chaparral" in Table 3), we multiplied the area of the canyon by \% Chaparral.

We estimated isolation of the canyons from each other and from unfragmented chaparral-like habitat using two kinds of distance measurements (Table 3). Distance $\mathrm{X}$ is the distance in meters to the nearest "source" canyon that contains the common chaparral-requiring species (Roadrunners, California Quail, California Thrasher, Rufous-sided Towhee, Bewick's Wren, and Wrentit). Distance $Y$ is the distance to the closest canyon that is equal or larger in size than the canyon being considered.

The variable Fox/Coyote is designed to assess the impact of mammalian predators on chaparral-requiring birds. Canyons were assigned values for the Fox/Coyote variable according to the following scheme: $1=$ gray 
Table 2. The distribution of chaparral-requiring species and predators.*

\begin{tabular}{|c|c|c|c|c|c|c|c|c|c|c|c|}
\hline \multirow[b]{2}{*}{ No. } & \multirow[b]{2}{*}{ Canyon } & \multirow[b]{2}{*}{ Wrentit } & \multirow{2}{*}{$\begin{array}{c}\text { Bewick's } \\
\text { Wren }\end{array}$} & \multirow{2}{*}{$\begin{array}{c}\text { Rufous- } \\
\text { sided } \\
\text { Towbee }\end{array}$} & \multirow[b]{2}{*}{ Thrasber } & \multirow[b]{2}{*}{ Quail } & \multirow[b]{2}{*}{ Roadrunner } & \multirow{2}{*}{$\begin{array}{c}\text { Black- } \\
\text { tailed } \\
\text { Gnatcatcber }\end{array}$} & \multirow{2}{*}{$\begin{array}{c}\text { Cactus } \\
\text { Wren }\end{array}$} & \multicolumn{2}{|c|}{ Predators } \\
\hline & & & & & & & & & & Coyote & Gray Fox \\
\hline 1 & Florida & 1 & 1 & 1 & 1 & 1 & & 1 & & & 1 \\
\hline 2 & Sandmark & 1 & 1 & 1 & 1 & 1 & 1 & & & 1 & 1 \\
\hline 3 & 34th St. & 1 & 1 & 1 & 1 & 1 & 1 & & & 1 & 1 \\
\hline 4 & Balboa $T$. & 1 & 1 & 1 & 1 & 1 & & & & 1 & 1 \\
\hline 5 & Alta L.J. & 1 & 1 & 1 & 1 & $\mathbf{1}$ & 1 & & & 1 & 1 \\
\hline 6 & Kate Ses. & 1 & 1 & 1 & 1 & 1 & 1 & & & 1 & 1 \\
\hline 7 & Pottery & 1 & & 1 & 1 & 1 & 1 & & & 1 & 1 \\
\hline 8 & Laurel & & & & & & & & & & 1 \\
\hline 9 & Cam. Cor. & 1 & 1 & 1 & 1 & & & & & 1 & \\
\hline 10 & Canon & & & & & & & & & & 1 \\
\hline 11 & Zena & 1 & 1 & & & 1 & & & & 1 & 1 \\
\hline 12 & Baja & 1 & 1 & 1 & & & & & & 1 & 1 \\
\hline 13 & Auburn & 1 & 1 & & & & & & & & 1 \\
\hline 14 & Washington & 1 & & & & & & & 1 & & 1 \\
\hline 15 & Solana Dr. & 1 & 1 & 1 & $\mathbf{I}$ & 1 & 1 & 1 & & 1 & \\
\hline 16 & Syracuse & 1 & 1 & 1 & 1 & 1 & 1 & & & 1 & 1 \\
\hline 17 & 32nd St. S. & 1 & & & & & & & & & 1 \\
\hline 18 & 47 th St. & 1 & & & & & & & & & 1 \\
\hline 19 & Mil Cumbres & 1 & 1 & 1 & 1 & 1 & 1 & & & 1 & \\
\hline 20 & Chollas & 1 & & & & & & & & 1 & 1 \\
\hline 21 & 60th St. & 1 & 1 & & & & & & & 1 & 1 \\
\hline 22 & Juan St. & 1 & 1 & & & & & & & 1 & 1 \\
\hline 23 & Acuna & 1 & 1 & 1 & & & & & & & \\
\hline 24 & Edison & 1 & 1 & & 1 & 1 & 1 & & & 1 & 1 \\
\hline 25 & Raffee & 1 & 1 & 1 & & & & & & 1 & 1 \\
\hline 26 & Spruce & & & & & & & & & & 1 \\
\hline 27 & Oak Crest & 1 & 1 & 1 & 1 & 1 & 1 & & & 1 & \\
\hline 28 & 54th St. & 1 & 1 & & & & & & & & 1 \\
\hline 29 & Titus & 1 & 1 & & & & & & & & 1 \\
\hline 30 & Chateau & 1 & 1 & 1 & & & & & & & \\
\hline 31 & Newport & 1 & & & & & & & & & \\
\hline 32 & Aber & 1 & 1 & & & & & & & & 1 \\
\hline 33 & Talbot & & & & & & & & & & 1 \\
\hline 34 & Montanosa & 1 & 1 & & 1 & 1 & 1 & & & 1 & \\
\hline 35 & Poinsettia & & & & & & & & & & \\
\hline 36 & El Mac & & & & & & & & & & 1 \\
\hline 37 & 32nd St. N. & 1 & & & & & & & & & 1 \\
\hline
\end{tabular}

* The scientific names of the birds are listed in Table 1.

foxes (Urocyon cinereoargenteus) present, coyotes (Canis latrans) present or absent; $2=$ foxes absent, coyotes absent; $3=$ coyotes present, foxes absent. We hypothesize that the presence of coyotes is beneficial because they control the number of gray foxes, domestic cats, and other avian predators, while rarely preying on birds themselves. A Fox/Coyote value 3 is, therefore, "best" for chaparral-requiring birds.

\section{The Census Technique}

Our objective was to sample the chaparral-requiring species exhaustively. The censuses were conducted from November 1985 to June 1986, and from September 1986 to February 1987. Some of the species were easier to detect in the spring, but there were no cases of chaparral-requiring species being detected in a canyon in the fall or winter that were absent from that canyon in the spring. Teams of two or more persons visited each site at least three times for two hours or more each time. The teams walked slowly through the area, recording the presence of each species seen or heard. Several observers visited each site in order to minimize individual differences between observers. If after three visits there was still any doubt about the presence of a particular species, additional visits were made to the site until we were satisfied that we had recorded each chaparralrequiring species present. There were no cases of disappearances of chaparral-requiring species from canyons during the course of this study. The occurrence of Roadrunners was based on the questionnaire (see below) and on interviews with residents living on canyon edges. The absence of Rufous-sided Towhees, a cryptic species that rarely sings in the fall, was verified by follow-up censuses in the winter and spring. The only chaparral-requiring species whose distribution appears 


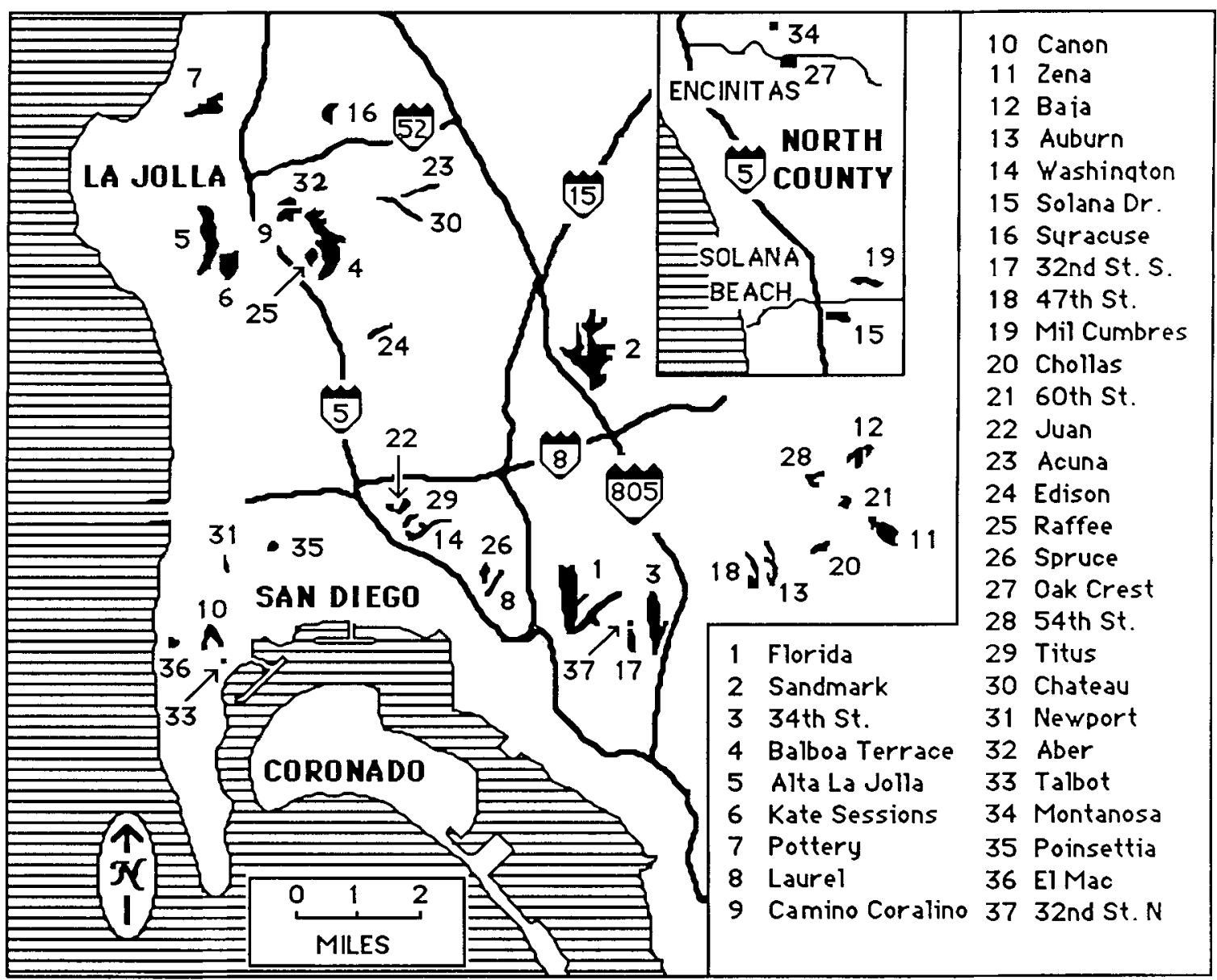

Figure 1. Map showing the location of the study sites (canyons) in the vicinity of San Diego, California.

to be determined by postfire succession is the Rufouscrowned Sparrow (Aimophila ruficeps); it was never observed by us.

In addition to the censuses, we distributed questionnaires to residents living on the edges of the canyons to obtain information about the distribution of vertebrate species that were not easily observed in the time period over which we sampled. These species included Roadrunners, coyotes, gray foxes, jackrabbits (Lepus californicus), brush rabbits (Sylvilagus bacbmani), raccoons (Procyon lotor), opossums (Didelpbus virginiana), skunks (Mephitis mephitus), and bobcats (Felis rufus). Suspicious or unexpected occurrences were checked by following up with telephone interviews or with further field work.

The smallest of our 37 sites is 32nd St. North. It is a "satellite" canyon of 32nd St. South, from which it is separated by a gap of only 25 to $45 \mathrm{~m}$. Statistical analyses showed 32nd St. North to be an outlier and an exceptionally influential observation. The Cook's distance and studentized deleted residual, calculated during a general linear model analysis of the variables shown in Table 4, were several times the magnitude of any other canyon.
For this as well as for other reasons explained below, it was excluded from the following analyses. When included, the general form of the results does not change, but the level of significance of the regressions is reduced.

Statistical analyses were performed with Statview (BrainPower, Inc., Calabasas, California) and SAS (SAS Institute, Inc., Carey, North Carolina) software.

\section{Results}

\section{Species-Area Relationships}

The species-area relationships for chaparral-requiring birds are shown in Figures $2 a$ and $2 b$. The apparent sigmoidal pattern of these curves is expected when the range of canyon size includes both habitat islands where the number of species $(S)$ is much less than the number of potential (or pool) species $(P)$ and habitat islands on which $S / P$ approaches 1.0 (Cain 1938, Diamond \& Mayr 1976, Gilpin \& Diamond 1976, Connor \& McCoy 1979). $S$ correlates more strongly with Chaparral (Fig. 
Table 3. Biogeographic data used in the multiple regressions analysis (variables defined in text).

\begin{tabular}{|c|c|c|c|c|c|c|c|c|c|}
\hline No. & Canyon & $\begin{array}{c}\text { No. Chaparral- } \\
\text { Requiring } \\
\text { Species }\end{array}$ & $\begin{array}{l}\text { Area } \\
\text { (ba) }\end{array}$ & $\begin{array}{c}\text { Chaparral } \\
\text { (ba) }\end{array}$ & $\begin{array}{c}\% \\
\text { Chaparral }\end{array}$ & $\begin{array}{c}\text { Dist. } \\
X \\
(m)\end{array}$ & $\begin{array}{c}\text { Dist. } \\
Y \\
(m) \\
\end{array}$ & $\begin{array}{l}\text { Age } \\
\text { (yrs) }\end{array}$ & $\begin{array}{c}\text { Fox/ } \\
\text { Coyote } \\
\end{array}$ \\
\hline 1 & Florida & 6 & 102.77 & 67.83 & 66 & 2100 & 2100 & 50 & 1 \\
\hline 2 & Sandmark & 6 & 84.05 & 75.65 & 90 & 914 & 914 & 20 & 1 \\
\hline 3 & 34th St. & 6 & 53.76 & 40.32 & 75 & 1676 & 853 & 34 & 1 \\
\hline 4 & Balboa T. & 5 & 51.77 & 38.82 & 75 & 243 & 121 & 34 & 1 \\
\hline 5 & Alta L.J. & 6 & 33.14 & 16.57 & 50 & 121 & 121 & 14 & 1 \\
\hline 6 & Kate Ses. & 6 & 25.56 & 15.33 & 60 & 822 & 121 & 16 & 1 \\
\hline 7 & Pottery & 5 & 17.92 & 10.75 & 60 & 700 & 45 & 14 & 1 \\
\hline 8 & Laurel & 0 & 9.72 & 0.49 & 5 & 1554 & 1554 & 79 & 1 \\
\hline 9 & Cam. Cor. & 4 & 9.08 & 8.62 & 95 & 331 & 61 & 20 & 3 \\
\hline 10 & Canon & 0 & 8.66 & 1.73 & 20 & 1219 & 1219 & 58 & 1 \\
\hline 11 & Zena & 3 & 8.51 & 2.55 & 30 & 2865 & 2865 & 36 & 1 \\
\hline 12 & Baja & 3 & 8.40 & 4.37 & 52 & 670 & 670 & 31 & 1 \\
\hline 13 & Auburn & 2 & 8.37 & 2.51 & 30 & 1737 & 1737 & 32 & 1 \\
\hline 14 & Washington & 2 & 8.07 & 1.31 & 15 & 365 & 365 & 74 & 1 \\
\hline 15 & Solana Dr. & 7 & 7.64 & 6.87 & 90 & 550 & 550 & 11 & 3 \\
\hline 16 & Syracuse & 5 & 7.51 & 6.38 & 85 & 40 & 40 & 18 & 1 \\
\hline 17 & 32th St. S. & 1 & 6.36 & .95 & 15 & 304 & 304 & 56 & 1 \\
\hline 18 & 47th St. & 1 & 6.31 & 2.52 & 40 & 1981 & 213 & 32 & 1 \\
\hline 19 & Mil Cumbres & 6 & 6.23 & 5.61 & 90 & 550 & 550 & 11 & 3 \\
\hline 20 & Chollas & 1 & 6.22 & 1.56 & 25 & 1005 & 1005 & 36 & 1 \\
\hline 21 & 60th St. & 2 & 6.11 & 2.14 & 35 & 2386 & 335 & 37 & 1 \\
\hline 22 & Juan St. & 2 & 5.97 & 2.99 & 50 & 228 & 228 & 23 & 1 \\
\hline 23 & Acuna & 3 & 5.08 & 1.52 & 30 & 662 & 110 & 22 & 2 \\
\hline 24 & Edison & 5 & 4.75 & 4.28 & 90 & 61 & 61 & 8 & 1 \\
\hline 25 & Raffee & 3 & 4.74 & 2.37 & 50 & 61 & 61 & 19 & 1 \\
\hline 26 & Spruce & 0 & 4.28 & 0.43 & 10 & 1767 & 1767 & 86 & 1 \\
\hline 27 & Oak Crest & 6 & 3.88 & 1.94 & 50 & 1000 & 400 & 6 & 3 \\
\hline 28 & 54th St. & 2 & 3.61 & 1.81 & 50 & 609 & 609 & 20 & 1 \\
\hline 29 & Titus & 0 & 3.50 & 0.25 & 7 & 335 & 280 & 77 & 1 \\
\hline 30 & Chateau & 3 & 3.27 & 1.80 & 55 & 304 & 110 & 20 & 2 \\
\hline 31 & Newport & 1 & 2.14 & 1.60 & 75 & 2895 & 2895 & 60 & 2 \\
\hline 32 & Aber & 2 & 1.60 & 1.04 & 65 & 331 & 91 & 15 & 1 \\
\hline 33 & Talbot & 0 & 1.41 & 1.27 & 90 & 1219 & 1219 & 55 & 1 \\
\hline 34 & Montanosa & 5 & 1.32 & 1.25 & 95 & 91 & 91 & 2 & 3 \\
\hline 35 & Poinsettia & 0 & 1.20 & 0.30 & 25 & 350 & 350 & 50 & 2 \\
\hline 36 & El Mac & 0 & 1.10 & 0.66 & 60 & 883 & 883 & 32 & 1 \\
\hline 37 & 32nd St. N. & 1 & 0.40 & 0.10 & 23 & 487 & 45 & 77 & 1 \\
\hline
\end{tabular}

2b) than with area (Fig. 2a). This suggests that the amount of chaparral habitat in a canyon is more important than total area in determining the number of chaparral-requiring species present. The semi-log plot, Figure $2 c$, is shown for comparison. In addition to these area effects, a strong effect of age on the number of chaparral-requiring species is apparent in Figure 3. "Older" canyons clearly have fewer species of chaparralrequiring birds. Bolger et al. (1988) provides further analysis of the species-age relationship.

Table 4. Product-moment correlation coefficients between variables in the multiple regression analysis (see Table 3 and text for definitions of these variables).

\begin{tabular}{|c|c|c|c|c|c|c|c|c|}
\hline & $s$ & In Area & In Chaparral & $\%$ Chaparral & In Dist. $X$ & In Dist. $Y$ & In Age & Fox/Coyote \\
\hline$S$ & 1 & & & & & & & \\
\hline In Area & 0.584 & 1 & & & & & & \\
\hline In Chaparral & 0.803 & 0.851 & 1 & & & & & \\
\hline$\%$ Chaparral & 0.645 & 0.114 & 0.584 & 1 & & & & \\
\hline In Dist. $X$ & -0.27 & 0.14 & -0.018 & -0.294 & 1 & & & \\
\hline In Dist. Y & -0.413 & 0.045 & -0.148 & -0.345 & 0.767 & 1 & & \\
\hline ln Age & -0.673 & 0.079 & -0.276 & -0.616 & 0.489 & 0.585 & 1 & \\
\hline Fox/Coyote & 0.352 & -0.281 & -0.048 & 0.4 & -0.107 & -0.234 & -0.538 & 1 \\
\hline
\end{tabular}

$\mathrm{p} \leqslant 0.01$ for coefficients $\geqslant 0.418 ; \mathrm{p} \leqslant 0.05$ for coefficients $\geqslant 0.325$. 


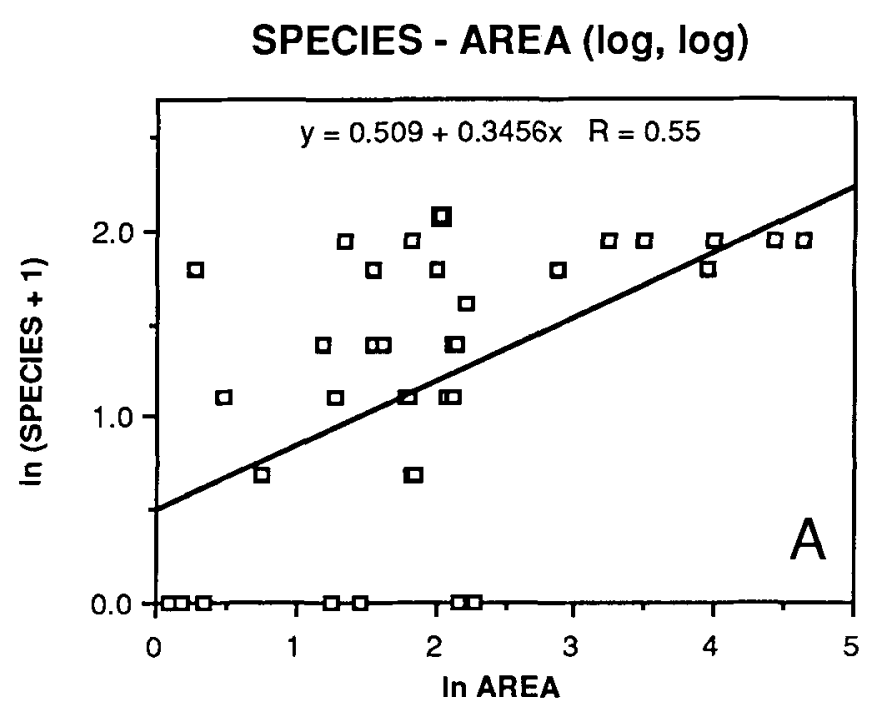

\section{SPECIES- CHAPARRAL AREA (semi-log)}

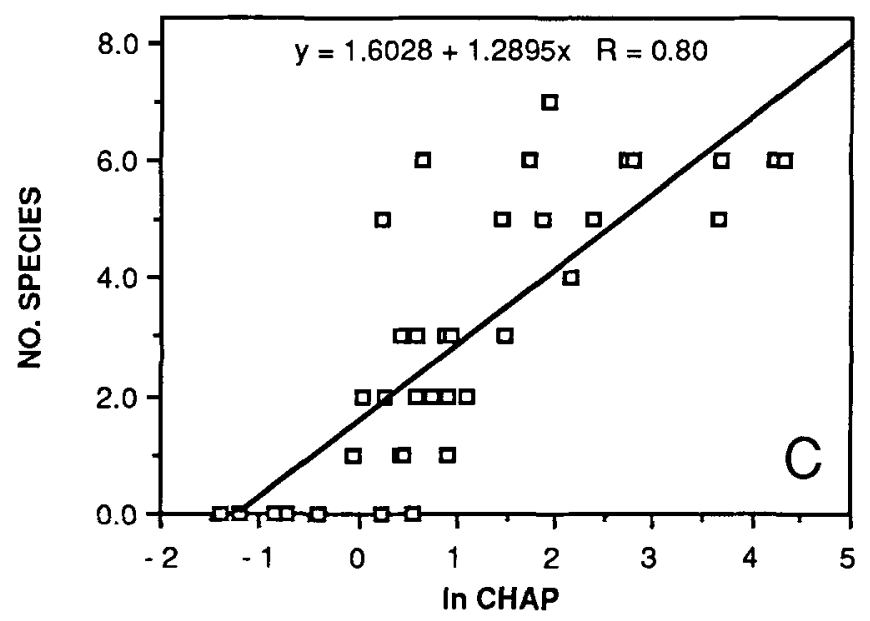

Nevertheless the covariation among Area, Chaparral, Age, and some of the other variables (Table 4) necessitates further analysis and explanation. Chaparral, for example, depends on two, independent factors: 1) the original area of the canyon, and 2) the cumulative loss of habitat since isolation or since the onset of disturbance. Figures $4 a$ and $4 b$ illustrate the association of absolute and relative loss of habitat, respectively. Based on inspection of Figure $4 b$, it appears that most canyons in this region will lose 90 percent or more of their natural cover within 90 years. Because variables such as Chaparral can confound habitat and time effects on species number, a more complex statistical methodology is needed to understand the interplay of potential causative factors.

\section{Stepwise Multiple Regression-Chaparral-Requiring Species}

Stepwise multiple regression (MR) was used to assess the possible contributions of the independent variables to $S$ while controlling for their covariation. In addition

\section{SPECIES - CHAPARRAL AREA (log, log)}

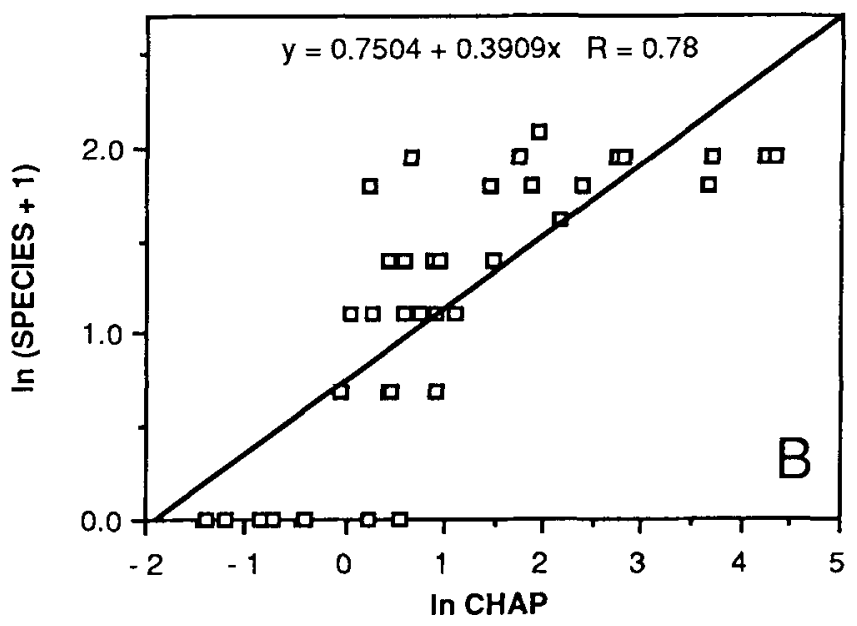

Figure 2. (A) Species-area (ba) relationship for chaparral-requiring bird species in 36 isolated canyons in western San Diego County, California. The value "1.0" is added to the number of chaparral-requiring species for computational purposes. (B) Same as A except that the abscissa is the bectarage of actual chaparral (natural babitat) in the canyons. (C) Same as $\mathrm{B}$ except that the number of species is not transformed to natural logs.

to the primary variables shown in Table 3, we tested many "secondary variables," including combinations of transformed variables and interaction variables (the pairwise products of Age, the distance variables, and Chaparral).

The combination of independent variables that gave the highest R-squared values was In Age, In Chaparral, In Area, and Fox/Coyote ("In" indicates that the values shown in Table 3 were transformed to natural logs). This set of predictors accounts for 90 percent of the variation in $S$ as shown in Table 5 , and $p<0.01$ for all steps in this regression analysis. The other variables in Table 3 do not add significantly to the adjusted $R$ squared when they are included in the same MR analysis with the above four. Residuals were normally distributed. Because a stopping rule ( $F$-to-enter $=4$ ) was used to select the independent variables, and the total number of candidate variables was greater than the number $(4)$ in the selected subset, the ordinary $F$ tables cannot be used; instead we used the tables provided by Wilkinson and Dallal (1981). 


\section{SPECIES AND AGE (TIME SINCE ISOLATION)}

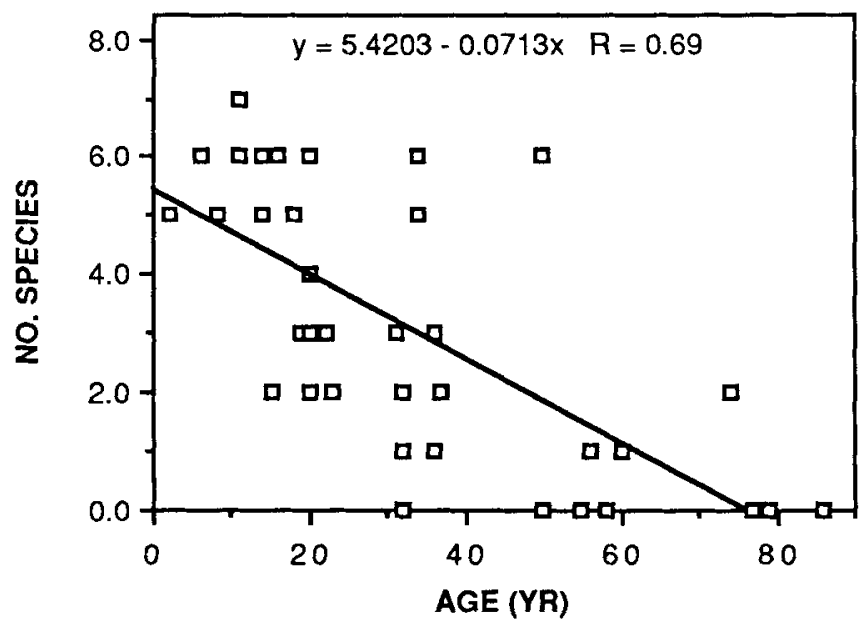

Figure 3. The relationship between number of chap. arral-requiring species and the number of years since canyon isolation (age).

\section{Discussion}

\section{The Evidence for Extinction}

Before discussing the results in detail, it is necessary to determine if the supposed extinctions of chaparralrequiring birds are real. Our results do not establish unequivocally that the chaparral-requiring species missing in a given canyon have become extinct. It is possible that the missing species were not present in a canyon at the moment of its separation. Indeed, it is quite likely that some of the smaller canyons may not have contained some of the rarer species, such as Black-tailed Gnatcatchers, Cactus Wrens, and Roadrunners, because the preferred habitats may have been lacking for some of these species, or they were absent, simply by chance, at the moment the canyons were isolated.

On the other hand, we have evidence that many of the chaparral-requiring species missing in canyons were present at the time of isolation. First, our youngest canyons, even the smallest ones, contain most of the chaparral-requiring species. The Montanosa ( $1.1 \mathrm{ha}$ ) and Oak Crest ( $3.9 \mathrm{ha}$ ) sites, for example, have five and six species, respectively, out of an observed maximum of seven chaparral-requiring species (Table 3 ). Second, speciesarea data from census plots in unfragmented habitat in nearby areas (Bolger et al. 1988) have low slopes ( $z=$ $0.13)$ when compared with those in this study ( $z[\ln$ Area $]=0.35 ; z[$ ln Chaparral $]=0.39$ ). Even the smallest census plots sampled ( $0.1 \mathrm{ha})$ had two or three chaparral-requiring species. This indicates that many of our canyons are indeed impoverished for bird species, and that most of the missing species, with the probable exceptions in some canyons of the Roadrunner, Cactus Wren, and Black-tailed Gnatcatcher, were once present in even the smallest canyons. Third, canyon age is a highly significant variable in the MR analysis, even after removing the correlated effect of reduction in habitat area with time (In Chaparral). Therefore, the most parsimonious interpretation is that species diversity in isolated canyons has decayed over time due to local extinctions.

\section{Causes of Extinction: The Roles of Area and Time Since Isolation}

Species diversity decreases with canyon age (Figure 3 and Table 4), and it appears that virtually all the chaparral-requiring species will disappear in a century, even in the largest canyons. A major factor contributing to these local extirpations appears to be the loss of habitat, some of which (such as fire) is catastrophic. Habitat attrition has many causes, including fires, removal for fire breaks, removal by residents (for gardens, orchards, kennels, etc.) and casual attrition due to recreational activities. The most disturbed canyons retain as little as 5 percent to 15 percent of their natural cover, the chaparral having been replaced by exotic Mediterranean grasses, forbs, and trees (palms and species of Eucalyptus, Acacia, etc.), by gardens, or by fire-retardant ground covers. Two of the variables in the MR analysis reflect the importance of space or habitat area. Chaparral estimates the amount of natural habitat in the canyons, while area measures the total amount of undeveloped open space. Some of the chaparral-requiring species may make use of open habitats, particularly the Roadrunner and the California quail. It is therefore possible that in Area contributes significantly because it accounts for some residual habitat area not estimated by Chaparral.

Table 5. Stepwise multiple regression analysis. All adjusted $\mathbf{R}^{2}$ values have associated $p$ values $<0.01$ according to tables in Wilkinson and Dallal (1981).

\begin{tabular}{|c|c|c|c|c|c|c|c|c|c|c|c|}
\hline \multirow[b]{3}{*}{$\underline{\text { Step }}$} & \multirow[b]{3}{*}{ Intercept } & \multirow{2}{*}{\multicolumn{2}{|c|}{ In Chaparral }} & \multicolumn{6}{|c|}{ Independent Variables } & & \\
\hline & & & & \multicolumn{2}{|c|}{ In Age } & \multicolumn{2}{|c|}{ Fox/Coyote } & \multicolumn{2}{|c|}{ In Area } & \multicolumn{2}{|c|}{ Adjusted Regression } \\
\hline & & $b$ & $F$ & $b$ & $F$ & $b$ & $F$ & $b$ & $F$ & $R^{2}$ & $F$ \\
\hline 1 & 1.6 & 1.23 & 61.7 & & & & & & & 0.63 & 61.66 \\
\hline 2 & 6.42 & 1.07 & 100.7 & -1.4 & 53.9 & & & & & 0.86 & 105.69 \\
\hline 3 & 4.55 & 2.23 & 122.7 & -1.1 & 25.3 & 0.57 & 6.2 & & & 0.88 & 83.61 \\
\hline 4 & 4.58 & 0.56 & 6.7 & -1.42 & 40.1 & 0.67 & 10.3 & 0.79 & 8.7 & 0.90 & 80.1 \\
\hline
\end{tabular}




\section{ASSOCIATION OF HABITAT AREA AND AGE}

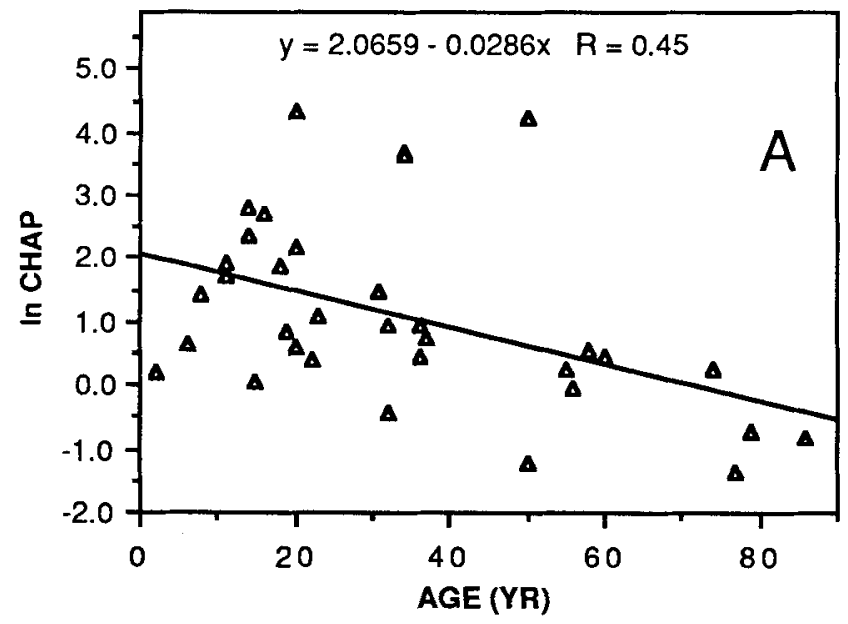

ASSOCIATION OF \% CHAP AND AGE

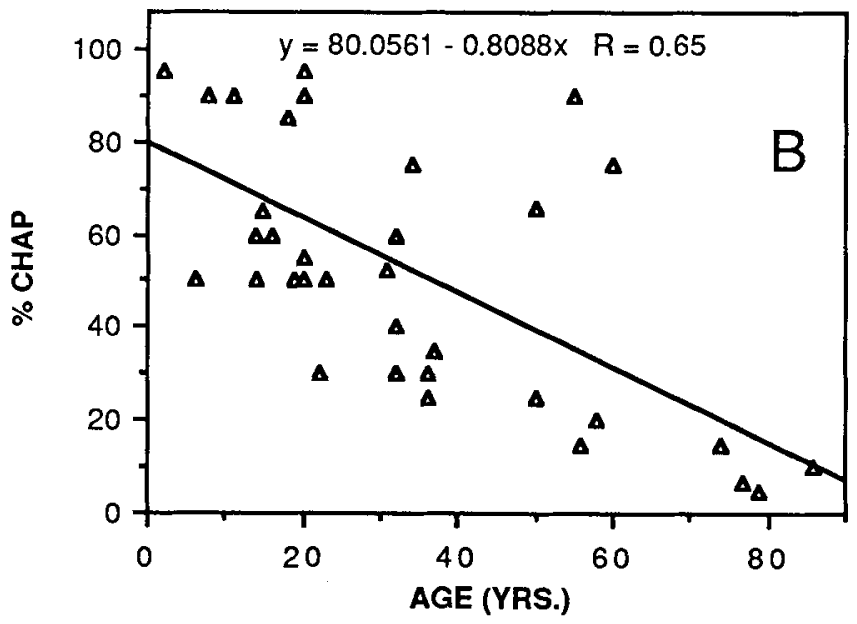

Figure 4. (A) The association between babitat area (ba) and time since isolation (age) for the canyons. (B) The association between the percent cover of natural habitat and the age for the canyons.

It was our impression that many extinctions occur before there has been much loss of habitat. This is consistent with the MR analysis, which shows Age to be important, independent of the effects of Chaparral and Area. Several mechanisms could account for early disappearances of chaparral-requiring species. These include 1) stochastic environmental variation in such variables as rainfall and temperature, 2) deterministic pressures such as predation, and 3) demographic stochasticity (Shaffer 1981, Gilpin \& Soulé 1986, Goodman 1987), especially in the smaller canyons. In addition, 4) when small populations persist for longer than a few generations, their uncertain fortunes are exacerbated by loss of heterozygosity and inbreeding (Frankel \& Soulé 1981, Gilpin \& Soulé 1986, Lande \& Barrowclough 1987). In theory, mechanisms 3 ) and 4) could play a major role in small canyons, assuming the mean number of individuals per species is quite low.

Based on the densities of each of the chaparralrequiring species in chaparral habitat, we have calculated the average population sizes of the chapartalrequiring species in hypothetical canyons of 2 ha and 20 ha (Table 6). These population sizes range from $<1.0$ to 10 individuals in 2 ha canyons, and from $<1.0$ to 100 individuals for hypothetical 100 ha canyons. Based on these low population sizes, we believe that rapid extinction of most chaparral-requiring species is inevitable in small canyons, given 1 ) the low vagility of these species, 2) random fluctuations in birth and death rates (Leigh 1981, Goodman 1987, Belovsky 1987), 3) normal stochastic variation in weather and brush fires, and 4) deterministic environmental factors such as predation that are discussed below. Isolated populations of this size will lose genetic variation at rates of up to 20 percent per generation. For example, a population with an effective size of 10 will lose additive genetic variation at an average rate of about 5 percent per generation, much too high for an outbreeding species to sustain for more than a few years (Franklin 1980, Soulé 1980, Allendorf \& Leary 1986).

When Area, Chaparral, and Age are log transformed, they explain more of the variation in species number than when untransformed. This is probably because of the nonlinear relationships between species number and both area and age. Species-area curves are typically curvilinear, even sigmoidal (Cain 1938, MacArthur \& Wilson 1967), and a $\log$ transformation is commonly used to linearize the relationship. Inspection of Table 3 will show that the number of chaparral-requiring species increases rather quickly as canyon size increases to about 20 ha, but levels out at that size (for canyons no older than 30 to 50 years). Therefore, canyons of 20 ha or larger probably have sufficiently large populations of most chaparral-requiring species to buffer them, at least in the short run, against the random events that quickly eliminate the same species in smaller canyons. Regarding the relative efficacy of Age vs. In Age, it has been recognized for some time (Diamond 1972, Terborgh 1974, Wilcox 1978, Gilpin \& Diamond, 1976, Soulé et al. 1979) that the relaxation rate in isolated patches is curvilinear, being high at first, and slowing later.

\section{Mesopredator Release}

In the absence of large, dominant predators, smaller omnivores and predators undergo population explosions, sometimes becoming four to 10 times more abundant than normal (Eisenberg et al. 1979, Terborgh \& Winter 1980, Glanz 1982, Emmons 1984). Similar explosions occur in spider populations in the absence of lizards on tropical islands (Pacala \& Roughgarden 1984, Schoener \& Spiller 1987). This phenomenon appears to be quite 
Table 6. Correlates of occurrence or vulnerability and estimated mean population sizes of the chaparral-requiring species in canyons of 2 ha and 20 ha in area at their moment of isolation.

\begin{tabular}{|c|c|c|c|c|c|}
\hline Species & $\begin{array}{c}\text { Density } \\
\left(\text { pairs ba } a^{-1}\right)^{*}\end{array}$ & $\begin{array}{c}\text { Body Weight } \\
(g)\end{array}$ & $\begin{array}{c}\text { Occurrence } \\
\text { (no. canyons) }\end{array}$ & $\begin{array}{l}\text { Estimated } \\
N \text { in } 2 b a\end{array}$ & $\begin{array}{c}\text { Estimated } \\
N \text { in } 20 b a \\
\end{array}$ \\
\hline Wrentit & 2.5 & 14.1 & 32 & 10 & 100 \\
\hline Bewick's Wren & 1.75 & 9.4 & 25 & 7 & 70 \\
\hline Rufous-sided Towhee & 1.29 & 37.0 & 16 & 5.2 & 51.6 \\
\hline California Thrasher & 1.10 & 93.5 & 15 & 4.4 & 44 \\
\hline Valley Quail & 0.96 & 184.2 & 15 & 3.84 & 38.4 \\
\hline Roadrunner & 0.02 & 304.0 & 11 & 0.1 & 0.8 \\
\hline Black-tailed Gnatcatcher $\dagger$ & 0.25 & ca 8.0 & 2 & 1 & 10 \\
\hline
\end{tabular}

* Data from Cody (1983 and personal communication, 1986)

+Population density estimate from Harold Wier (personal communication, 1986).

general; we refer to it as "mesopredator release." The term mesopredator in this context was suggested by Larry Harris (personal communication, 1987). Mesopredator release has been implicated in some of the bird extinctions on Barro Colorado island and other localities (Willis \& Eisenmann 1979, Matthiae \& Stearns 1981, Whitcomb et al. 1981; see Wilcove et al. 1986 for discussion).

In our analysis, the Fox/Coyote variable is designed to represent the interactions between coyotes, foxes, and domestic cats, and to estimate the impact of those animals on chaparral-requiring birds. The results are consistent with the hypothesized roles and interactions of these predators (methods). Fox/Coyote is a minor but significant predictor of $S$ in the MR analysis (Table 4). There is also circumstantial and anecdotal evidence that gray foxes and domestic cats are a major factor in the disappearance of wildlife from canyons. Gray foxes frequently prey on birds, especially those that nest on or close to the ground (Ewer 1973), and they tend to be more arboreal than other canids. Cats are usually "subsidized" predators - most of their food is provided by human benefactors, and bird predation is a leisure time activity for many of them. Consequently, there is virtually no limit to the number of cats that can occur in an urban canyon. Domestic cats can continue to take wildlife in a canyon long after the density of prey is too low to sustain a native predator that must rely on wildlife for most of its food. At present we cannot say how much damage cats are doing, but other studies have shown that birds constitute as much as 19 percent (Eberhard 1954) or 25 percent (Hubbs 1951) of the stomach contents (by volume) of feral cats. One pet cat in Michigan ate 62 birds during a period of 18 months (Bradt 1949). This would be enough predation to wipe out several of the rarer species from a small canyon. There is abundant evidence for the disappearance in urban areas of bird species that nest on or near the ground, and cats are usually implicated (Tomialojc 1982, Emlen 1974, Weber 1975).

The significance of Fox/Coyote (Table 4) suggests to us that coyotes are helping to control the smaller pred- ators (including cats) in the canyons, possibly contributing to the maintenance of the native, chaparral avifauna. At first, this may sound contradictory because coyotes are predators and will eat birds on occasions but coyotes rarely prey heavily on birds, even relatively sedentary species like quail (Leach \& Frazier 1953). Instead they feed mostly on rabbits, rodents, and opportunistically on smaller predators and omnivores such as foxes and cats (Korschgen 1957).

Coyotes apparently are common and ubiquitous in recently isolated canyons, whereas foxes are rare or absent (Tables 2 and 3). Other bird predators, such as raccoons, skunks, and opossums, all of which are preyed on by coyotes (Young \& Jackson 1951, Korschgen 1957, Beckoff 1978), are much more frequently reported in older, highly disturbed canyons than in large or young canyons (unpublished data). Therefore, both statistical and circumstantial evidence point to mesopredator release as a significant factor in the disappearance of chaparral-requiring bird species from isolated canyons.

Based on the considerations in this and the preceding sections, the avifaunal collapse in the canyons is likely the product of three interacting phenomena or processes. First, there is a primary wave of extinctions initiated by random demographic and genetic events, compounded by environmental variability. Second, these stochasticities are exacerbated by predation, especially cat and fox predation, which tends to press larger populations to the domain of the random processes. Third, chronic habitat loss eventually exposes all of the chaparral-requiring birds, even those in the largest canyons, to the stochasticities that constitute the first group of phenomena. This illustrates the operation of the interacting extinction vortices described by Gilpin and Soulé (1986).

\section{Species Vulnerability}

Certain chaparral-requiring species appear to be more vulnerable to local exinction than others. Diamond (1975a) has used incidence functions to illustrate the 
relationship between occupation (the proportion of patches occupied) and a biogeographic variable such as patch size. In Figure 5a, we have plotted incidence as a function of Chaparral area. It is evident that some species achieve 100 percent occupancy before others. Wrentits and Bewick's Wrens, for example, occupy virtually 100 percent of canyons that have 7 ha or more of habitat, whereas California thrashers require areas of about 20 ha to achieve full occupancy. Taken together, these results are consistent with the hypothesis that spe-

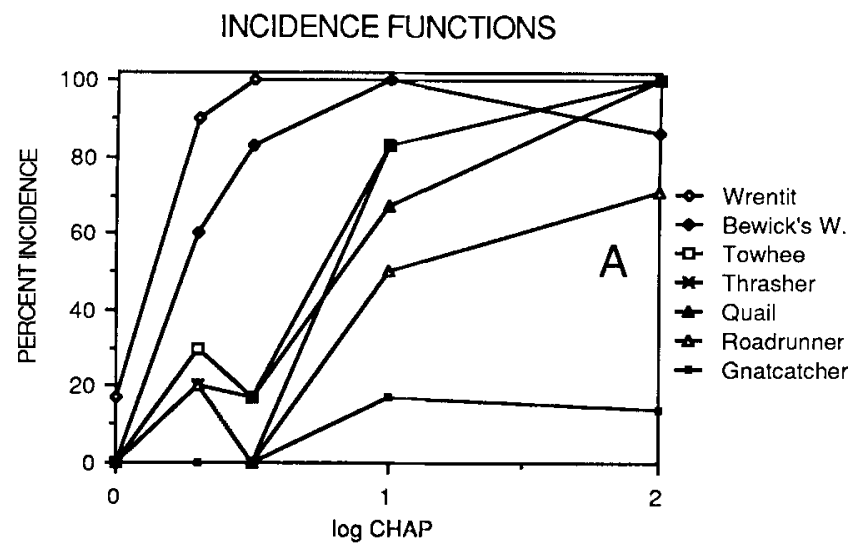

INCIDENCE: "Old" versus "Young"

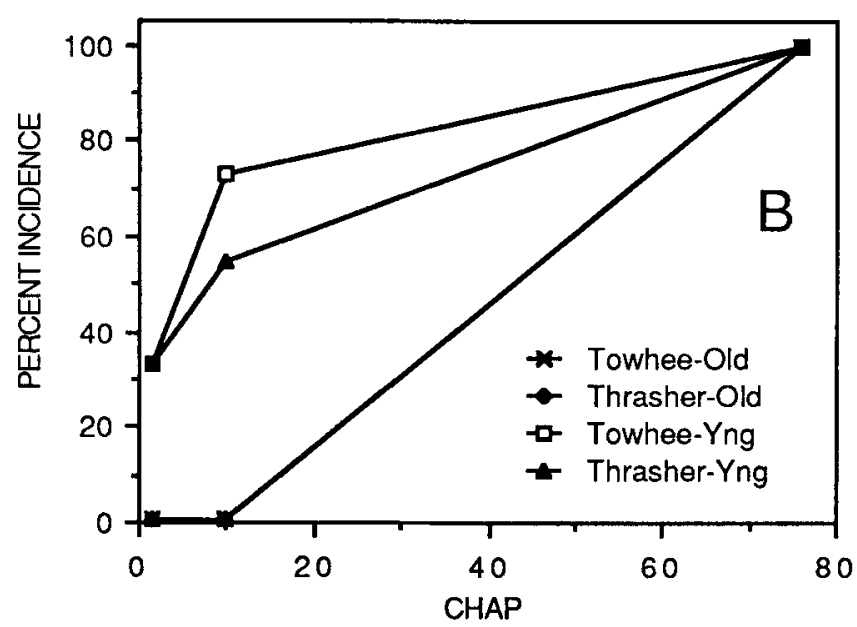

Figure 5. (A) Incidence functions of seven species of chaparral-requiring birds in isolated canyons in San Diego. The canyons were divided into five groups based on habitat "CHAP" of six to 10 canyons each. The ranges of areas of the five groups are 1) $<1.0$ ba, 2) 1.0 to $1.99 \mathrm{ba}, 3) 2.0$ to $3.99 \mathrm{ba}$ 4) 4.0 to 9.99 ha 5) 10 to $100 \mathrm{ba}$. The abscissa is graduated in $\log _{10}$ units. (B) Incidence functions for two moder. ately abundant species of chaparral-requiring birds. "Yng" refers to incidence functions based on canyons with "ages" less than 32 years. "Old" refers to incidence functions based on canyons that are "older" than 32 years. cies disappear from isolated canyons in a predictable order, namely Black-tailed Gnatcatcher, Roadrunner, California Quail, [California Thrasher and Rufous-sided Towhee], Bewick's Wren, and Wrentit.

In theory, incidence functions in these canyons should have shifted to the right with time, as species gradually drop out of canyons. In other words, incidence at the moment of isolation should have been higher for most size categories of canyons, especially the smaller ones, than it is now. To test this hypothesis, we analyzed the data for Rufous-sided Towhees and California Thrasher. These species were chosen because they have intermediate levels of vulnerability, though the data for the other chaparral-requiring species follow the same pattern. The incidence functions compare recently isolated ( $<32$ years since isolation) with the older ( 32 to 88 years) canyons. Each of these two groups was divided into three size categories for this analysis, a number that allowed at least three canyons in each size category. Evidence for the predicted incidence shift with canyon "age" is shown in Figure $5 b$. The only "old" canyons that retain these two species are those that are larger than 50 ha.

What factor or factors explain the difference in relative vulnerability of these species? Terborgh and Winter (1980) and Diamond (1984) surveyed a number of factors that might account for the differences in extinction vulnerability. Both surveys concluded that rarity or naturally low population density was most important, though other factors, such as body size (Belovsky 1987), trophic level, dependence on patchy or seasonal resources (Karr 1982a) and temporal variation in population size (Karr 1982b, Newmark 1987, chapters in Soulé 1987) might be significant or even paramount in some circumstances. Body size is thought to be important because larger animals are better buffered against short-term changes in resource availability and weather (Pimm et al. 1988).

Here we examine two hypotheses that might account for the order of chaparral-requiring species disappearance in canyons: 1 ) the body size hypothesis, and 2) the abundance (or rarity) hypothesis. The average body weights and estimates of populations densities of these species are tabulated in Table 6 . The correlation between body size and the number of canyons in which a species occurs is nonsignificant $(r=-0.3 ; p=0.51)$.

The best single predictor that we have found for the occurrence of particular species in canyons is the estimated average population density of the species in undisturbed habitat. The highly significant relationship $(r=0.93 ; p=0.0025)$ between abundance and persistence is shown in Figure $6 a$ Further support of the abundance hypothesis is provided by the incidence analysis. The order in which species disappear from canyons (Fig. $5 a$ ) is virtually the same as the ranking of the 
ASSOCIATION OF ABUNDANCE AND OCCURRENCE

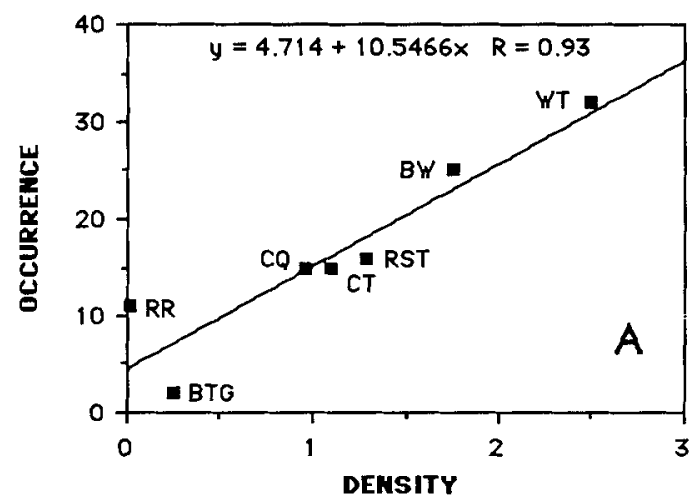

PARTIAL CORRELATION OF WEIGHT AND OCCUPANCY

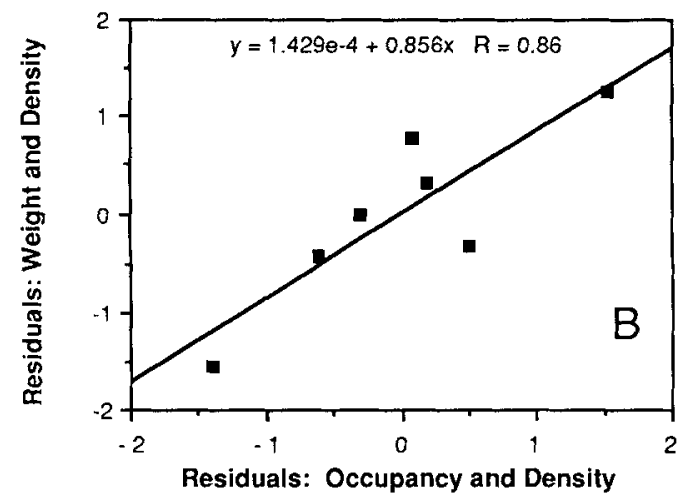

Figure 6. (A) The association of density (in pairs per ba) in relatively undisturbed habitat and the num. ber of canyons in which a species of chaparral-requiring bird occurs. $R R=$ Roadrunner; $B T G=$ Black-tailed Gnatcatcher; $C Q=$ California Quail; $C T=$ California Thrasher, RST $=$ Rufous-sided Towhee; $B W=$ Bewick's Wren; $W T=$ Wrentit. (B) Regression of the residuals of density on weight and occupancy demonstrating the significant association of weight and occupancy after statistically removing the effect of density; $p<0.02$.

species abundance in Table 6 . This also suggests a causeeffect relationship between abundance and vulnerability. Our results add yet another example to the substantial number of cases where population size or density is an important general predictor of vulnerability to extinction (see also Diamond et al. 1987).

Might some of the variation in occupancy that is unexplained by abundance $\left(1-R^{2}=0.14\right)$ be attributed to an effect of body size? MR analyses (Table 7) show that most of the residual variation in canyon occupancy is indeed removed by the addition of body size to the regression. As shown in Figure $6 b$, the partial correlation between occupancy and body weight, holding density constant, is $0.86, p<0.02$. Together, abundance and body size explain about 95 percent of the variation in canyon occupancy. The results are slightly more sig- nificant when the independent variable is the arcsin of the square root of the proportion of occupied canyons. It will be worthwhile to continue surveying the younger, more saturated, canyons, in order to test whether the order of disappearance of their chaparralrequiring species is predictable from this two-factor causation hypothesis.

\section{Predicting the Future}

Multiple regression is often used to obtain an equation that is used for predictive purposes. Urban planners and conservationists wishing to anticipate the fate of chaparral-requiring birds in habitat fragments could use an equation derived from the MR analysis. The equation (from Table 4) is

$$
\begin{aligned}
S=4.58- & 1.42 \ln \text { Age }+0.56 \ln \text { Chaparral }+0.79 \\
& \ln \text { Area }+0.67 \text { Fox/Coyote }
\end{aligned}
$$

Such an equation can be used to predict the number of species of chaparral-requiring birds in a canyon at some time in the future, assuming conditions stay the same. Say, for example, that a 4 ha canyon was to be isolated by a pending subdivision. One might want to estimate the number of species of chaparral-requiring birds that would remain in the canyon in five years, 25 years, and 75 years. Assuming for the sake of simplicity that the Fox/Coyote value is 3 (coyotes present, foxes absent), and using the above equation, the corresponding numbers of chaparral-requiring species are $5.41,3.12$, and 1.56 , respectively. (The 95 percent prediction intervals around these values are approximately plus or minus 1.9 species.)

Because nearly all canyons lose natural habitat with time, let us assume that 25 percent of the chaparral has been replaced by nonnative vegetation in 25 years, and that 50 percent is replaced in 75 years. Recalculating the number of surviving chaparral-requiring species with these reductions in habitat gives 2.95 in 50 years and 1.17 in 75 years, respectively.

We caution that predictions such as these are rough approximations, both for statistical and biogeographic reasons. Nevertheless, this statistical tool can provide planners with a qualitative estimate of the impact of fragmentation. Because our sample of canyons lacks cases of very small "satellite" canyons (like the deleted outlier 32 St. North), the above equation should not be used to predict extinctions in such canyons.

\section{Is Chaparral More Vulnerable to Faunal Collapse than Forest?}

Relaxation might occur more quickly in fragmented Mediterranean scrub habitats than in temperate forest fragments, patch sizes being equal. One reason is that these scrub habitats are more brittle, so habitat loss will 
Table 7. Stepwise multiple regression analyses of factors contributing to the number of canyons occupied by the particular chaparral-requiring species (all $p$ values are $<0.01$ ).

\begin{tabular}{|c|c|c|c|c|c|c|c|}
\hline \multirow[b]{3}{*}{ Step } & \multirow[b]{3}{*}{ Intercept } & \multicolumn{4}{|c|}{ Independent Variable } & \multirow[b]{3}{*}{ Adjusted $R^{2}$} & \multirow[b]{3}{*}{ Regression $F$} \\
\hline & & \multicolumn{2}{|c|}{ Density } & \multicolumn{2}{|c|}{ Weight } & & \\
\hline & & $b$ & $F$ & $b$ & $F$ & & \\
\hline 1 & 4.71 & 10.55 & 31.28 & & & 0.84 & 31.28 \\
\hline 2 & -1.44 & 13.23 & 92.38 & 0.034 & 10.62 & 0.94 & 51.02 \\
\hline \multicolumn{8}{|c|}{ Dependent variable $=$ arcsin of square root of $\%$ of canyons occupied: } \\
\hline 2 & 0.127 & 0.424 & 114.41 & 0.0013 & 18.67 & 0.95 & 60.57 \\
\hline
\end{tabular}

occur at higher rates. This relative fragility of chaparral habitat is accounted for by several factors, including lower levels of precipitation, and the vulnerability of the vegetation to irreversible destruction by frequent burning, trampling, and, in parts of the world, overbrowsing by domesticated animals. Whereas the destruction of a forest usually requires considerable energy, the effects of traffic alone in chaparral habitat can cause the replacement of a patch of scrub with grassland or other exotic, xeric-adapted species.

Another reason for the relatively high rates of faunal collapse of some chaparral biotas, in this case the chaparral-requiring birds, is their low vagility (Johnson 1972, Power 1972, Jones \& Diamond 1976). The complete absence of some of these species from the California Islands is suggestive. For example, the very common Wrentit and the California Thrasher do not occur on any of the California Islands (Johnson 1972) in spite of large areas of suitable habitat. The Roadrunner is also absent (Jones \& Diamond 1976). Low vagility alone will lead to rapid relaxation because remnant populations cannot be "rescued" (Brown and Kodric-Brown 1977) by occasional dispersing individuals, and because recolonization (replacement of extirpated species) of canyons will rarely occur. In contrast, facultative chaparral birds often migrate or disperse through nonnative habitats such as suburbs or farmland.

These two reasons, then, habitat fragility and low vagility, appear to account for the rapid collapse of chaparral-requiring bird communities in the fragments of canyon habitat. (The two rarest species in our canyons, Black-tailed Gnatcatcher and Cactus Wren, are relatively strong flyers, but they are also extremely rare throughout the entire urbanized coastal region.)

The canyon fragments, therefore, may represent true islands to the chaparral-requiring birds. Why, then, did none of the isolation variables enter any of the MR analyses? Jones et al. (1985) remarked on the absence of an isolation effect for refugial populations of reptiles, suggesting an inability to recolonize across inhospitable habitat following local extinction. Our results are similar and consistent with the hypothesis that immigration is virtually negligible if the development barrier is wider than 50 to $100 \mathrm{~m}$, at least in the time scale of a century or so. The presence of the Wrentit in the small outlier satellite canyon, 32nd St. North, does not contradict this hypothesis. The distance between this canyon and the larger $32 \mathrm{nd}$ St. South is only 30 to $45 \mathrm{~m}$, and because the larger canyon also has Wrentits, we suggest that the narrowness of the habitat gap permits occasional exchange. Our sample of 37 canyons did not include other such satellite canyons, precluding the statistical resolution of such a truncated distance effect. (The MR equation predicts that 32 nd St. North should have -2 species. We attribute this to the dominance of chaparral and age.)

\section{$Z$ Values: Vagility and Relaxation}

Preston (1962), MacArthur and Wilson (1967) and (May 1975) predicted that most $z$ values would fall within the range $0.15-0.35$ for the power ( $\log -\log$ ) form of the species-area curve. Other factors, however, can account for values within this range. Connor and McCoy (1979) point out that $z$ values in the range $0.2-0.4$ are "characteristic of any regression system with a high $r$ value and a small range in the dependent variable $[S]$ relative to that in the independent variable [area]." It may not be legitimate, therefore, to speculate about the $z$ values in this study, but we note that the slopes of our species-areas curves ( 0.35 and 0.39 for area and chaparral, respectively) approach the upper limit of the "null" range. Many examples of even higher $z$ values are in the literature (e.g., Culver et al. 1973, Case 1983, Jones et al. 1985, Martin 1981a, Connor \& McCoy 1979 , Rusterholz \& Howe 1979).

Some of the reported values of $z$ above 0.4 are associated with archipelagoes that comprise small islands or island-like isolates. Several studies have described such high $z$ values for vagile birds. Rusterholz and Howe (1979), Martin (1981a), and Howe (1984) obtained $z$ values of $0.44,0.40$, and 0.39 to 0.62 for birds on small islands in a Minnesota lake, for forest (shelterbelt) islands in South Dakota, and for isolated forest patches in New South Wales, respectively. Rusterholz and Howe (1979) and Martin, (1981a) interpreted their results 
according to a model developed by Schoener (1976). Schoener's model predicts that a combination of competition, high vagility, and $S<<P$ would produce steep slopes (approaching 0.5 ), conditions that apparently apply in the Rusterholz and Howe (1979) and Martin (1981a) studies.

The paradox is that we observe an even higher $z$ value for very small habitat islands, even though our situation is virtually the opposite of that predicted by Schoener: competition among our chaparral-requiring species is problematic, vagility is very low, and $S / P$ is high. We obtain a $z$ value of 0.64 for the relationship of ln Chaparral and $\ln S$ for the set of canyons with Chaparral $<7$ ha, the same upper bound for island size used by Howe (1984), who obtained $z$ values of 0.39 and 0.62 for total species and resident birds, respectively.

Is there a reasonable explanation for the high slopes of the species-area curves in systems that differ so greatly in the variables considered important by Schoener? Jones et al. (1985) state that "A steep slope probably reflects a low or nonexistent rate of colonization [Case 1983] and limits on species occurrence imposed by small island size [Martin 1981b]." These conditions apparently apply to the canyon-chaparral-requiring bird system. First, in our system the y-intercept is very low because many of the smaller patches lack any chaparralrequiring species. (Note that these vacant patches are large enough to support one or more pairs of many of the chaparral-requiring species [Table 6] assuming the birds were capable of finding the empty patches.) Second, on inspection of Figure 3 it is apparent that the vacant or near-vacant canyons are among the "oldest" in the survey. Such canyons appear to be too small to sustain many chaparral-requiring species for more than a few decades. If the dispersal and colonizing abilities of these species were greater, then the slope of the species-area curve would obviously be lower. A third factor accounting for the steep slope is the near saturation of small "young" canyons that still retain most of their chaparral-requiring species. Taken together, these three factors describe a system in the process of relaxation.

Hence, an alternative explanation for high $z$ values is the relaxation process itself. Briefly, an archipelago, such as the small subset ( $<7$ ha) of canyons, comprising a mixture of old and young islands, or relaxed and unrelaxed biotas, will necessarily produce a high slope, but only during the process of relaxation (Brown 1971, Diamond 1972). Before relaxation begins, the $z$ is low and the intercept is high (Bolger et al. 1988). When, several decades later, the canyons have lost most of their chaparral-requiring species, the slope will again be low. In the meantime, however, the larger and younger canyons still retain many of their chaparral-requiring species, while the smaller and older ones have already lost most of theirs; this size-related but transient asymmetry accounts for the high slopes.
Clearly, quite different sets of conditions can lead to high slopes for species-area curves, especially for small islands. We have discussed two such sets (Schoener's model: high vagility and low $S / P$; our nonequilibrium model: low vagility, and high $S / P$ ). There are likely to be several others. For example, Blake and Karr (1984) reported a $z$ value of 0.57 for migratory, forest-interior birds in isolated forest tracts in Illinois. One of the reasons for this pattern is apparently a pronounced threshold effect: habitat islands smaller than about 25 ha appear to be unsatisfactory for breeding; those patches larger than 100 ha are acceptable to about five or more species. On a $\log$ scale this produces a very high $z$, especially when $S<<P$.

\section{Potential Migration Measures}

Is there any way to abate the rapid and dramatic decline in chaparral-requiring bird species in isolated canyons? Other students of fragmentation (e.g., Goldstein et al. 1981, Beissinger \& Osborne 1982, Vizyová 1986) have suggested some principles (mostly referring to maximizing patch size and complexity) for mitigating the effects of fragmentation in urban areas, but these proposals concern mostly forest species, so their relevance is probably greater for non-chaparral-requiring birds than for chaparral-requiring species.

For relatively sedentary species, connectivity of patches is probably the most important landscape feature for maintaining species diversity of native biota. In the long run, habitat corridors linking two or more patches are likely to be the cheapest and most effective treatments. Corridors, even relatively narrow ones, counteract the effects of fragmentation, and should eliminate or minimize the attrition of species over time by facilitating dispersal and recolonization (Willis 1974, Diamond 1975, Brown \& Kodric-Brown 1977, Frankel \& Soulé 1981, Harris 1984, Soulé \& Simberloff 1985 , Noss \& Harris 1986, Forman \& Godron 1986, Diamond et al. 1987, Noss 1987).

A question that naturally arises concerns the minimum width of corridors. To our knowledge, there have been no studies of this issue, but our own observations suggest that most, if not all, of the chaparral-requiring species can use relatively narrow strips of vegetation. We have observed Wrentits and Rufous-sided Towhees taking advantage of strips as narrow as $1 \mathrm{~m}$. California Quail, California Thrashers, and Bewick's Wren have been observed in strips less than $10 \mathrm{~m}$ in width, and we believe that corridors half this width probably would be effective, as long as the chaparral was dense and formed a nearly continuous cover. Further studies would be necessary to determine if taxa such as reptiles and mammals require a different geometry of corridors and patches.

With proper planning and execution, existing or 
planned linear stretches of open area or amenities, such as highway and freeway verges and roadcuts, power line rights of way, sections of parks, and, possibly, hiking and bicycle paths, could serve as wildlife corridors. Where feasible, vegetated underpasses should be constructed to link natural habitat that is being fragmented by road and highway construction. Such underpasses would also reduce the number of animals killed on highways; could help prevent the local extirpation of large or rare species such as mule deer (Odocoileus bemionus), bobcat, and mountain lion (Felis concolor); and could serve hikers and bicyclists. Corridors permitting the movement of coyotes will probably minimize mesopredator release.

Many authors have commented on the possible disadvantages of corridors (Frankel \& Soulé 1981, Soulé \& Simberloff 1986, Simberloff \& Cox 1987, Noss 1987). These include poaching, exposure, and transmission of disease and parasites, the spread of fire, and some possible genetic and ecological drawbacks. Most of these potential biological problems, however, apply to remnant populations of large animals that are rare or endangered. When dealing with common species of wildlife in urban or suburban settings, these problems pale in significance when compared to the advantages of corridors.

Finally, we raise the possibility of the reintroduction of native birds into depauperate canyons. Such projects would be feasible under certain circumstances, and could be managed by state, county, or city agencies, or by neighborhood, school, or conservation groups. There are many technical issues that should be considered before such projects are instituted, but we feel that the "reanimation" of defaunated habitat fragments is a socially and biologically desirable objective for planners and conservationists.

\section{Summary}

1. Chaparral-requiring species of birds have very high rates of extinction in isolated canyons in the San Diego area. Most species disappear within a few decades following the isolation (by development) of habitat patches.

2. Habitat area and time since isolation are significantly correlated with the current number of surviving species. These factors probably reflect the roles of space and population size in determining the viability of isolated groups. The prompt disappearance of many populations in small canyons is expected, given the combination of 1) very small populations in recently isolated canyons, 2) low vagility of the chaparral-requiring species, and 3 ) the unavoidability of random demographic, genetic, and environmental events. Those populations that survive for a few decades will eventually succumb as habitat attrition and predation press their populations below the thresholds where stochastic events overpower their genetic fitness and reproductive capacities.

3. Our data are consistent with the growing body of evidence suggesting that the elimination of large predators from a system can be destabilizing. In the absence of large predators, smaller predators can become more abundant (mesopredator release) and, in turn, may cause the local extinction of vulnerable prey species. It appears that coyotes may lower the rate of extinction of chaparral-requiring birds by reducing the abundance of smaller predators, including gray foxes and the ubiquitous domestic cat.

4. The vulnerability of particular species appears to be highly predictable in these canyons. Persistence probability is highly correlated with population density in relatively undisturbed habitat. Large-bodied birds, however, seem to persist longer than smaller birds of equal abundance.

5. Chaparral birds may be more vulnerable to local extinction than forest birds, in part because of the poor dispersal abilities of the former, especially in a fragmented landscape.

6. Slopes ( $z$ values) of species-area curves for the chaparral-requiring species are high, especially for canyons with less than 7 ha of chaparral. Such high slopes can occur under several sets of conditions, including, as in this study, when the set of islands includes both relaxed and relatively unrelaxed biotas.

7. The most effective tool for the prevention of extinction of chaparral-requiring species in an urban landscape is the prevention of fragmentation in the first place by proper planning of urban and suburban development. Corridors of natural habitat, even quite narrow ones, are probably very effective in permitting dispersal between patches, thereby preventing or minimizing faunal collapse.

\section{Acknowledgments}

We wish to thank the following individuals who have provided advice, assistance, and criticism: Steven Beissinger, Carl Biehl, Sheila Brown, Martin Cody, Claude Edwards, Richard Etheridge, Lee Ann Hayek, Sally Howe, Lee McClenaghan, Steven Montgomery, Stuart Pimm, Amadeo Rea, Christine Tratnyek, Howard Wier, the hundreds of citizens who kindly returned questionnaires, and the San Diego Advisory Commission for Fish and Wildlife for financial assistance. Michael Gilpin's collaboration was essential, and Jared Diamond and an anonymous reviewer provided many helpful and substantive editorial suggestions.

\section{Literature Cited}

Allendorf, F. W., and R. F. Leary. 1986. Heterozygosity and fitness in natural populations of animals. Pages 57-74 in M.E. 
Soulé, editor. Conservation biology: the science of scarcity and diversity. Sinauer Associates, Sunderland, Massachusetts, USA.

Beckoff, M., editor. 1978. Coyotes: biology, behavior and management. Academic Press, New York, New York, USA.

Beissinger, S. R., and D. R. Osborne, 1982. Effects of urbanization on avian community organization. Condor 84:75-83.

Belovsky, G. E. 1987. Extinction models and mammalian persistence. Pages 35-58 in M. E. Soulé, editor. Viable populations for conservation. Cambridge University Press, Cambridge, England, and New York, New York, USA.

Blake, J. G., and J. R. Karr. 1984. Species composition of bird communities and the conservation benefit of large versus small forests. Biological Conservation 30:173-187.

Bolger, D. T., A. C. Alberts, and M. E. Soulé. 1988. Rapid extinction in fragmented habitat produces nested species subsets. Submitted.

Bradt, G. W. 1949. Farm cat as a predator. Michigan Conservation 18:25-26.

Brown, J. H. 1971. Mammals on mountaintops: nonequilibrium insular biogeography. American Naturalist 105:467-478.

Brown, J. H. 1978. The theory of insular biogeography and the distribution of boreal birds and mammals. Great Basin Naturalist Memoirs 2:209-227.

Brown, J. H., and A. Kodric-Brown. 1977. Turnover rates in insular biogeography: Effect of immigration on extinction. Ecology 58:445-449.

Burgess, R. C., and D. M. Sharp, editors. 1981. Forest island dynamics in man-dominated landscapes. Springer-Verlag, New York, New York, USA.

Cain, S. A. 1938. The species-area curve. The American Midland Naturalist 19:573-581.

Case, T.J. 1975. Species numbers, density compensation and colonizing ability of lizards on islands in the Gulf of California. Ecology 56:3-18.

Case, T. J. 1983. The reptiles: ecology. Pages in T. J. Case and M. L. Cody, editors. Island biogeography in the Sea of Cortez. University of California Press, Berkeley, California, USA.

Cody, M. L. 1983. Parallel evolution and bird niches. Pages 307-338 in F. di Castri and A. A. Mooney, editors. Mediterranean Type Ecosystems: Origin and Structure. Springer-Verlag, New York, New York, USA. Ecological studies, no. 23. Mediterranean-type ecosystems: the role of nutrients. SpringerVerlag, New York, New York, USA.

Cody, M. L. 1986. Diversity, rarity, and conservation in Mediterranean-climate regions. Pages 123-152 in M. E. Soulé, editor. Conservation biology: the science of scarcity and diversity. Sinauer Associates, Sunderland, Massachusetts, USA.

Connor, E. F., and E. D. McCoy. 1979. The statistics and biology of the species-area relationship. American Naturalist 113:791-833.
Culver, D., J. R. Holsinger, and R. Bargody. 1973. Toward a predictive cave biogeography: the Greenbriar Valley as a case study. Evolution 27:689-695.

Diamond, J. M. 1972. Biogeographic kinetics: estimation of relaxation times for avifaunas of southwest Pacific islands: Proceedings of the National Academy of Sciences (USA ) 69:31993203.

Diamond, J. M. $1975 a$. Assembly of species communities. Pages 342-444 in M. L. Cody and J. M. Diamond, editors. Ecology and evolution of communities. Harvard University Press, Cambridge, Massachusetts, USA.

Diamond, J. M. 1975b. The island dilemma: lessons of modern biogeographic studies for the design of natural reserves. Biological Conservation 7:129-146.

Diamond, J. M. 1984. Distribution of New Zealand birds on real and virtual islands. New Zealand Journal of Ecology 7:3755.

Diamond, J. M., and R. M. May. 1976. Island biogeography and the design of nature reserves. Pages $163-186$ in R. M. May, editor. Theoretical ecology. Saunders Publishing Co., Philadelphia, Pennsylvania, USA.

Diamond, J. M., and E. Mayr. 1976. Species-area relation for birds of the Solomon Archipelago. Proceedings of the National Academy of Sciences (USA) 73:262-266.

Diamond, J. M., K D. Bishop, and S. van Balen. 1987. Bird survival in an isolated Javan woodland: island or mirror? Conservation Biology 1:132-142.

Eberhard, T. 1954. Food habits of Pennsylvania house cats Journal of Wildlife Management 18:284-286.

Eisenberg, J., M. O'Connell, and P. V. August. 1979. Density, productivity, and distribution of mammals in two Venezuelan habitats. Pages 187-207 in J. F. Eisenberg, editor. Vertebrate ecology in the northern Neotropics. Smithsonian Institute Press, Washington, D.C., USA.

Emlen, J. T. 1974. An urban bird community in Tucson, Arizona: derivation, structure, regulation. The Condor 76:184197.

Emmons, L. E. 1984. Geographic variation in densities and diversities of non-flying mammals in Amazonia. Biotropica 16:210-222.

Ewer, R. F. 1973. The carnivores. Cornell University Press, Ithaca, New York, USA.

Forman, R. T. T., and M. Godron. 1986. Landscape ecology. John Wiley \& Sons, New York, New York, USA.

Frankel, O. H., and M. E. Soulé. 1981. Conservation and evolution. Cambridge University Press, New York, New York, USA, and Cambridge, England.

Franklin, I. R. 1980. Evolutionary change in small populations. Pages 135-150 in M. E. Soulé and B. A. Wilcox, editors. Conservation biology: an evolutionary-ecological perspective. Sinauer Associates, Sunderland, Massachusetts, USA. 
Gilpin, M. E., and J. M. Diamond. 1976. Calculation of immigration and extinction curves from the species-area-distance relation. Proceedings of the National Academy of Sciences (USA) 73:4130-4134.

Gilpin, M. E., and M. E. Soulé. 1986. Minimum viable populations: process of species extinctions. Pages 19-34 in M. E. Soulé, editor. Conservation biology: the science of scarcity and diversity. Sinauer Associates, Sunderland, Massachusetts, USA.

Glanz, W. E. 1982. The terrestrial mammal fauna of Barro Colorado Island: censuses and long-term changes. Pages 239-251 in E. G. Leigh, A. S. Rand, and D. M. Windsor, editors. The ecology of a tropical forest. Smithsonian Institute Press. Washington, D.C., USA.

Goldstein, E. L., M. Gross, and R. M. DeGraaf. 1981. Explorations in bird-land geometry. Urban Ecology 5:113-134.

Goodman, D. 1987. The demography of chance extinction. Pages 11-34 in M. E. Soulé, editor. Viable populations for conservation. Cambridge University Press, Cambridge and New York.

Harris, L. D. 1984. The fragmented forest: island biogeography theory and the preservation of biotic diversity. University of Chicago Press, Chicago, Illinois, USA.

Heaney, I. R. 1986. Biogeography of mammals in SE Asia: estimates of rates of colonization, extinction and speciation. Biological Journal of the Linnaean Society 28:99-125.

Howe, R. W. 1984. Local dynamics of bird assemblages in small forest habitat islands in Australia and North America. Ecology 65:1585-1601.

Hubbs, E. L. 1951. Food habits of feral house cats in the Sacramento Valley. California Fish and Game 37:177-189.

Johnson, N. K. 1972. Origin and differentiation of the avifauna of the Channel Islands, California. Condor 74:295-315.

Jones, K B., L. P. Kepner, and T. E. Martin. 1985. Species of reptiles occupying habitat islands in western Arizona: a deterministic assemblage. Oecologia 66:595-601.

Jones, H. F., and J. M. Diamond. 1976. Short-time-base studies of turnover in breeding bird populations on the California Channel Islands. Condor 77:526-549.

Karr, J. R. 1982a. Population variability and extinction in the avifauna of a tropical land bridge island. Ecology 63:19751978.

Karr, J. R. 1982b. Avian extinction on Barro Colorado Island, Panama: a reassessment. American Naturalist 119:220-239.

Korschgen, L. J. 1957. Food habits of the coyote in Missouri, Journal of Wildlife Management 21:424-435.

Lande, R., and G. R. Barrowclough. 1987. Effective population size, genetic variation, and their use in population management. Pages 87-124 in M. E. Soulé, editor. Viable populations for conservation. Cambridge University Press, Cambridge and New York.
Lawlor, T. E. 1986. Comparative biogeography of mammals on islands. Biological Journal of the Linnaean Society 28:99-125.

Leach, H. R., and W. H. Frazier. 1953. A study of the possible extent of predation on heavy concentrations of valley quail with special reference to the bobcat. California Fish and Game 39:527-538.

Leigh, E. G. 1981. The average lifetime of a population in a varying environment. Journal of Theoretical Biology 90:213239

Lynch, J. F., and D. F. Whigham. 1984. Effects of forest fragmentation on breeding bird communities in Maryland, USA Biological Conservation 28:287-324.

MacArthur, R. H., and E. O. Wilson. 1967. The theory of island biogeography. Princeton University Press, Princeton, New Jersey, USA.

Martin, T. E. $1981 a$ Limitation on small habitat islands: chance or competition? Auk 98:715-734.

Martin, T. E. $1981 b$. Species-area slopes and coefficients: a caution on their interpretation. American Naturalist 118:823837.

Matthiae, P. E., and F. Stearns. 1981. Mammals in forest islands in southeastern Wisconsin. Pages 55-66 in R. L. Burgess and D. M. Sharpe, editors. Forest Island Dynamics in ManDominated Landscapes. Springer-Verlag, New York, New York, USA.

May, R. M. 1975. Patterns of species abundance and diversity. Pages 81-120 in M. L. Cody and J. M. Diamond, editors. Ecology and evolution of communities. Belknap, Cambridge, Massachusetts, USA.

Newmark, W. D. 1987. A land-bridge island perspective on mammalian extinctions in western North American parks. Nature 325:430-432.

Noss, R. F. 1987. Corridors in real landscapes: a reply to Simberloff and Cox. Conservation Biology 1:159-164.

Noss, R. F., and L. D. Harris. 1986. Nodes, networks and MUMs: preserving diversity at all scales. Environmental Management 10:299-309.

Pacala, S., and J. Roughgarden. 1984. Control of arthropod abundance by Anolis lizards on St. Eustatius (Neth. Antilles). Oecologia 64:160-162.

Patterson, B. D. 1984. Mammalian extinction and biogeography in the southern Rocky Mountains. Pages 247-293 in M. H. Nitecki, editor. Extinctions. University Chicago Press, Chicago, Illinois, USA.

Pimm, S. L., H. L. Jones, and J. M. Diamond. 1988. On the risk of extinction. Submitted.

Power, D. M. 1972. Numbers of bird species on the California islands. Evolution 26:451-463.

Preston, F. W. 1962. The canonical distribution of commonness and rarity. Ecology 43:185-215. 
Rusterholz, K. A., and R. W. Howe. 1979. Species-area relations of birds on small islands in a Minnesota lake. Evolution $33: 468-477$.

Schoener, 'T. W. 1976. The species-area relation within archipelagos: Models and evidence from island land birds. Proceedings of the Sixteenth International Ornithology Congress 1976:629-642.

Schoener, T. W., and D. A. Spiller. 1987. Effect of lizards on spider populations: manipulative reconstruction of a natural experiment. Science 236:949-952.

Shaffer, M. L. 1981. Minimum population sizes for species conservation. BioScience 31:131-134.

Simberioff, D. and J. Cox. 1987. Consequences and costs of conservation corridors. Conservation Biology 1:63-71.

Soulé, M. E. 1980. Thresholds for survival: maintaining fitness and evolutionary potential. Pages 151-169 in M. E. Soulé and B. A. Wilcox, editors. Conservation biology: an evolutionaryecological perspective. Sinauer Associates, Sunderland, Massachusetts, USA.

Soulé, M. E., editor. 1987. Viable populations for conservation. Cambridge University Press, Cambridge and New York.

Soulé, M. E., and D. Simberloff. 1986. What do genetics and ecology tell us about the design of nature reserves. Biological Conservation 35:19-40.

Soulé, M. E., and A. J. Sloan. 1966. Biogeography and distribution of the reptiles and amphibians on islands in the Gulf of California, Mexico. Transactions of the San Diego Society of Natural History 14:137-156.

Soulé, M. E., B. A. Wilcox, and C. Holtby. 1979. Benign neglect: a model of faunal collapse in the game reserves of East Africa. Biological Conservation 15:260-272.

Terborgh, J. 1974. Preservation of natural diversity: the problem of extinction prone species. BioScience 24:715-722.

Terborgh, J. 1975. Faunal equilibria and the design of wildlife preserves. Pages 369-380 in F. Golley and E. Medina, editors. Tropical ecological systems: trends in terrestrial and aquatic research. Springer-Verlag, New York, New York, USA.

Terborgh, J., and B. G. Winter. 1980. Some causes of extinction. Pages 119-131 in M. E. Soulé and B. A. Wilcox, editors.
Conservation biology: an ecological-evolutionary perspective. Sinauer Associates, Sunderland, Massachusetts, USA.

Tomialojc, L. 1982. Synurbanization of birds and the prey predator relations. Pages 131-139 in Animals in urban environment: the proceedings of symposium Warszawa-Jablonna, 22-24 September 1979. Ossolineum, Wroclaw (ISBN 83. 04-01126-3).

Vizyová, A. 1986. Urban woodlots as islands for land verte. brates: a preliminary attempt on estimating the barrier effects of urban structural units. Ekológia (CSSR) 5:407-419.

Weber, W. C. 1975. Nest-sites of birds in residential areas of Vancouver, British Columbia. The Canadian Field-Naturalist 89:457-460

Whitcomb, R. F., S. S. Robbins, J. F. Lynch, B. L. Whitcomb, M. K. Klimkiewicz, and D. Bystrak. 1981. Effects of forest frag mentation on avifauna of the eastern deciduous forest. Pages 125-292 in R. L. Burgess and D. M. Sharpe, editors. Forest island dynamics in man-dominated landscapes. SpringerVerlag, New York, New York, USA

Wilcove, D. S., C. H. Mclellan, and A. P. Dobson. 1986. Habitat fragmentation in the Temperate Zone. Pages 237-256 in M. E. Soulé, editor. Conservation biology: the science of scarcity and diversity. Sinauer Associates, Sunderland, Massachusetts, USA.

Wilcox, B. A. 1978. Supersaturated island faunas: a species-age relationship for lizards on post-Pleistocene land-bridge islands. Science 199:996-998.

Wilcox, B. A. 1980. Insular ecology and conservation. Pages 95-117 in M. E. Soulé and B. A. Wilcox, editors. Conservation biology: an evolutionary-ecological perspective. Sinauer Associates, Sunderland, Massachusetts, USA.

Wilkinson, L., and G. E. Dallal. 1981. Tests of significance in forward selection regression with an $F$-to enter stopping rule. Technometrics 23:377-380

Willis, E. O. 1974. Populations and local extinctions of birds on Barro Colorado Island, Panama. Ecological Monographs 44:153-169.

Willis, E. O., and E. Eisenmann. 1979. A revised list of birds on Barro Colorado Island, Panama. Smithsonian Contributions in Zoology 291:1-31.

Young, S. P., and H. T. Jackson. 1951. The clever coyote. Wildlife Management Institute, Washington, D.C., USA. 